\title{
EDUKASI PENGGUNAAN ANTIBIOTIK YANG TEPAT DALAM MENANGANI INFEKSI PADA MASYARAKAT DESA SUNGAI LULUT
}

\author{
Dede Mahdiyah ${ }^{1}$, Bayu Hari Mukti ${ }^{2}$, Tintin Rostini ${ }^{3}$, Ahmad Rushadi', \\ Kharlinia Eprianti ${ }^{1}$ \\ ${ }^{1}$ Fakultas Kesehatan, Program Studi Farmasi, Universitas Sari Mulia \\ ${ }^{2}$ Fakultas Pendidikan Biologi, STKIP PGRI Banjarmasin \\ ${ }^{3}$ Fakultas Peternakan, Universitas Islam Kalimantan \\ Email : mahdiyahdede@yahoo.co.id
}

\begin{abstract}
ABSTRAK
Pengunaan obat antibiotik yang tidak tepat masih menjadi masalah utama salah satu penyebab terjadinya kasus resistensi bakteri terhadap antibiotik. Rendahnya pengetahuan masyarakat dalam menggunakan obat antibiotik yang tepat dan masih banyaknya menggunakan obat tersebut tanpa harus ada resep dokter menjadi masalah utama yang harus diselesaikan pada kegiatan pengabdian kepada masyarakat. Tujuan kegiatan pengabdian kepada masyarakat untuk memberikan pengetahuan tentang penggunaan antibiotik yang tepat dalam menangani penyakit infeksi. Kegiatan ini dilaksanakan oleh dosen dan mahasiswa di Desa Sungai Lulut, Kecamatan Banjarmasin Timur, Kota Banjarmasin, Kalimantan Selatan. Tahapan kegiatan pengabdian ini yaitu; memberikan materi kepada masyarakat, diskusi, dan mengevaluasi program. Masyarakat di Desa Sungai Lulut sangat antusias dan responsip dalam kegiatan ini dan juga mulai mengetahui pentingnya penggunaan antibiotik yang tepat.
\end{abstract}

Kata Kunci: edukasi, infeksi, penggunaan antibiotik, Desa Sungai Lulut.

\section{PENDAHULUAN}

Antibiotik adalah obat yang digunakan untuk mengobati penyakit infeksi yang disebabkan oleh bakteri (Mahdiyah et al., 2020). Antibiotik merupakan obat yang sering diresepkan untuk pasien namun sering terjadi penggunaan yang tidak tepat dan berakibat terjadinya resistensi terhadap kuman. Akibat efek terapi antibiotik yang diberikan cukup cepat dalam mengobati infeksi, tidak jarang masyarakat menggunakannya secara tidak tepat. Perilaku penggunaan antibiotik yang tidak tepat ini, meliputi tidak menghabiskan obat antibiotik sesuai aturannya, menggunakan antibiotik secara berlebihan, menggunakan antibiotik yang tidak dibutuhkan, dan membeli serta menggunakan antibiotik tanpa resep. Hal ini terjadi karena kurangnya pengetahuan masyarakat tentang penggunaan antibiotik yang tepat. Permasalahan resistensi terjadi ketika bakteri berubah dalam satu atau lain hal yang menyebabkan turun atau hilangnya efektivitas obat, senyawa kimia atau 
bahan lainnya yang digunakan untuk mencegah atau mengobati infeksi. Penyebab utama resistensi antibiotik ialah penggunaannya yang meluas dan irasional (Permenkes RI, 2011).

Menurut hasil penelitian tentang Antimicrobial Resistant in Indonesia menunjukkan dari 2.494 individu di masyarakat, $43 \%$ Escherichia coli resisten terhadap berbagai jenis antibiotik (MDR (Multidrugs Resistance) antara lain: ampisilin (34\%), kotrimoksazol (29\%) dan kloramfenikol (25\%). Tidak hanya itu, resistensi Escherichia coli di Indonesia juga terjadi terhadap trimethoprimsulphamethoxazole $(56 \%)$ dan ciprofloxacin (22\%) (Hadi et al., 2010). WHO mengeluarkan Global Strategy for Containment of Antimicrobial Resistance, yaitu dokumen yang ditujukan kepada para pembuat kebijakan agar mendesak pemerintah di berbagai negara untuk melakukan tindakan dan berbagai usaha yang dapat mencegah terjadinya resistensi antibiotik. Maka dari itu, perlu dilakukan edukasi yang berkaitan dengan penggunaan antibiotik, agar tingkat pengetahuan dan pemahaman masyarakat tentang penggunaan antibiotik yang tepat dapat tercapai sehingga dapat menghindari hal-hal yang tidak diinginkan. Pemberian edukasi bagi masyarakat umum dalam meningkatkan kesadaran terhadap upaya pengendalian penyebaran penyakit infeksi dapat dilakukan dengan cara mendorong penggunaan antibiotik yang bijak. Kegiatan edukasi yang disertai dengan sosialisasi tentang kebijakan dan prosedur restriksi antibiotik dapat meningkatkan efektivitas edukasi.

\section{METODE PELAKSANAAN}

\section{Waktu Kegiatan}

Kegiatan pengabdian kepada masyarakat ini dilaksanakan pada bulan Februari 2021.

\section{Tempat Kegiatan}

Tempat pelaksanaan pengabdian kepada masyarakat di wilayah Desa Sungai Lulut, Kecamatan Banjarmasin Timur, Kabupaten Banjarmasin.

\section{Tahapan Pelaksanaan Kegiatan}

Pelakasanaan kegiatan pengabdian dengan tema edukasi tentang penggunaan antibiotik yang tepat dalam menanganai infeksi memiliki tahapan seperti;

1. Penyampaian materi tentang penggunaan antibiotik yang tepat

2. Diskusi

3. Evaluasi Program. 


\section{Tim kegiatan}

Kegiatan ini dilaksanakan oleh dosen pengampu dan mahasiswa (Tabel 1).

Tabel 1. Tim kegiatan pengabdian kepada masyarakat

\begin{tabular}{lll}
\hline No & Nama & Uraian Tugas \\
\hline 1 & Dr. Dede Mahdiyah, M.Si & $\begin{array}{l}\text { Menyusun artikel, } \\
\text { Membuat rencana kegiatan, } \\
\text { melaksanakan kegiatan } \\
\end{array}$ \\
2 & Bayu Hari Mukti, S.Hut., M.Si & $\begin{array}{l}\text { Membuat rencana kegiatan, } \\
\text { melaksanakan kegiatan } \\
\text { Membuat rencana kegiatan, } \\
\text { melaksanakan kegiatan }\end{array}$ \\
3 & Dr. Ir. Tintin Rostini, M.P & melaksanakan kegiatan \\
& & melaksanakan kegiatan \\
4 & Ahmad Rushadi & melaksanakan kegiatan \\
& melaksanakan kegiatan \\
\hline
\end{tabular}

\section{HASIL DAN PEMBAHASAN}

Pada kegiatan ini kami bersama tim memberikan edukasi kepada masyarakat tentang penggunaan antibiotik yang tepat ketika sakit. Masyarakat di Sungai Lulut sangat antusias dan tertarik dalam kegiatan kami. Masyarakat juga mulai memahami tentang konsep penggunaan obat antibiotik, dan masyarakat juga mulai menyadari kesalahan yang pernah dilakukannya yaitu menggunakan obat tanpa saran dari dokter, sehingga pada kegiatan ini menghasilkan pengetahuan masyarakat yang meningkat tentang:

1. Penggunaan obat antibiotik yang bijak

2. Penggunaan obat harus ada anjuran dari dokter sebelumnya
3. Pemahaman tentang penggunaan obat antibiotik, dan

4. Pemahaman tentang infeksi dan penyebab infeksi.

Berikut adalah dokumentasi kegiatan pengabdian masyarakat yang dilaksanakan di Desa Sungai Lulut, Banjarmasin, Kalimantan Selatan. (Gambar 1)
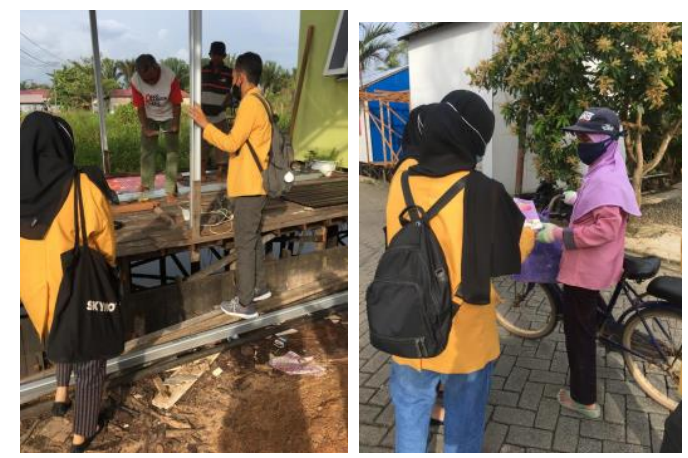

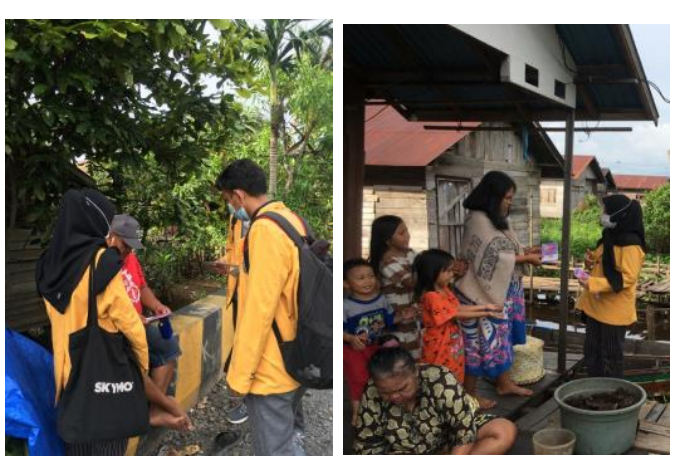

\section{KESIMPULAN}

Kegiatan pengabdian kepada masyarakat yang dilakukan di Desa Sungai Lulut sangat bermanfaat bagi masyarakat dalam menggunakan obat antibiotik yang tepat ketika sakit agar terhindar dari penyalahgunaan antibiotik (swamedikasi) dan juga untuk mencegah terjadinya kasus resistensi bakteri penyebab sakit terhadap antibiotik.

\section{DAFTAR PUSTAKA}

Hadi, U. et al. (2010) 'Cross-sectional study of availability and pharmaceutical quality of antibiotics requested with or without prescription (Over The Counter) in Surabaya, Indonesia', BMC Infectious Diseases, 10. doi: 10.1186/1471-2334-10-203.

Mahdiyah, D. et al. (2020) 'Screening of Indonesian peat soil bacteria producing antimicrobial compounds', Saudi Journal of Biological Sciences. vol 27(10): 2604-2611.

doi:

10.1016/j.sjbs.2020.05.033.

Permenkes RI (2011) 'Peraturan Menteri Kesehatan Republik Indonesia Nomor 2406/MENKES/PER/XII', Pedoman Umum Penggunaan Antibiotik, pp. 34-44. 